\title{
Survey on the English Translations of Brief Introductions to the Universities in Hebei Province
}

\author{
Leyang Wang \\ English Department \\ North China Electric Power University (Baoding) \\ Baoding, China
}

\begin{abstract}
This essay surveys the English translations of Brief Introductions to the Universities in Hebei Province. The survey showed that they were not of consistent quality. The mistakes were divided into five groups: writing mechanics mistakes, punctuation marks mistakes, mistaken translations of proper nouns, confusing translations, and negligence of cultural differences. English global communication materials can be considered as a visiting card for the outside world to get a chance to deepen its knowledge of Hebei Province. Yet there is still a way long way for Hebei Province to go. In order to make good impressions to foreigners, international writing mechanics and punctuation marks rules should be followed. And translators are expected to employ officially-approved translations of proper nouns. Last but not least, the cultural differences cannot be neglected during the translation process.
\end{abstract}

Keywords-translation; global communication; crosscultural communication; cultural difference

\section{INTRODUCTION}

Since the implementation of the Reform and Opening-up policy, China has been attaching great importance to foster a good and healthy image in the international community. Global communication is regarded as a transnational activity, which plays a key role in promoting the socialistic modernization of our country. In 2015, the Outline of Collaborative Development of Beijing, Tianjin and Hebei Province was approved by the Political Bureau of the CPC Central Committee, bringing a marvelous opportunity for Hebei Province. One of the key tasks proposed in the Outline is to open wider to the outside world. On this aspect, Hebei Province is expected to quicken her pace to catch up with Beijing and Tianjin.

Although Hebei Province is very close to both Beijing and Tianjian, it attracts less attention of the international community. Global communication materials can be considered as a visiting card for the outside world to get a chance to deepen its knowledge of Hebei Province. Accordingly, the translation of those materials occupies a vital position and plays an important role.

Does the translation quality of the global communication materials in Hebei Province meet the need of opening wider

Supported by "The Humanities and Social Science Research Program for the Universities in Hebei Province issued by Hebei Education Department, SZ16240 to the outside world? This essay hereby tries to make a survey on the translation quality of the global communication materials in Hebei Province. Limited by the length of this essay, only the brief introductions to the universities in Hebei province are discussed.

\section{METHOD}

The data were collected from the English web sites of the relevant universities. Both the English versions and Chinese versions were collected with the aim to make comparisons between them.

The reasons why the brief introductions to the universities were selected are as follows. First, among all the universities in Hebei Province, twenty four universities possess an English web site, making it easier for foreigners to collect information they are interested in. And it is convenient and appropriate to collect data, too. Secondly, despite the fact that the content of the English web pages in all the above universities varies greatly from one to another, it includes an English brief introduction on the English web pages in all the 24 universities. Finally, these twenty four universities enroll overseas students. Therefore, the English web sites play an important role in publicizing the corresponding university's international image. Then, those universities do their utmost to write and polish their English pages. The translation is thus of comparatively high quality. The three reasons mentioned above can guarantee the objectivity and comprehensiveness of the data collection.

After the data have been collected, they were analyzed with reference to their corresponding Chinese versions. The mistakes were divided into the following groups: writing mechanics mistakes, punctuation marks mistakes, mistaken translations of proper nouns, confusing translations, and negligence of cultural differences.

As to writing mechanics mistakes and punctuation marks mistakes, the rules listed in English Writing Mechanics: Writer's Handbook were regarded as the standard, because this handbook is edited according to the international norms. Certain proper nouns may be translated differently, although they share almost the similar meanings. The officially approved translations listed in New Age Chinese-English Dictionary were considered as standard translations in this essay. 


\section{RESULT}

The English brief introduction to a university is supposed to be of high quality, for there are many English teachers in every university, who are capable of both English and Chinese. However, the survey showed quite contrary results. The English brief introductions were not of consistent quality among the 24 universities. Some were well translated, with few conspicuous mistakes, while others were poorly translated, even unreadable in some sense. The mistakes were directly quoted word for word from the English translations of the brief introductions to the twenty four mentioned universities and hereby divided into different groups and analyzed in detail.

\section{A. Writing Mechanics Mistakes}

A common saying goes, "Nothing can be accomplished without norms or standards." Chinese and English belong to different language families. They differ not only in grammar, but in writing mechanics. The writing mechanics mistakes in the English translations of the brief introductions to the universities in Hebei Province were summarized here.

\section{1) Misusage of Numbers}

Example 1: 80 scholars are awarded honorary titles by the State, Province and Ministry of Education.

\section{Example 2: two hundred thousand square meters}

In general, numbers of one hundred or less are spelled out and those over one hundred are written in figures. However, when a number begins a sentence, it must be spelled out, even if it has more than two digits. Although the figure 80 in example 1 contains only two digits, it must be spelled out because of its beginning a sentence. In example 2 , the number two hundred thousand should not be spelled out, because it contains six digits, and it does not begin a sentence.

\section{2) Misusage of Capitalized Letters}

Example 3: the $11^{\text {th }}$ five-year National Developing Program

\section{Example 4: more than 140 million RMB in value \\ Example 5: only 280KM south to Beijing}

The capitalizing rule says that the first word and content words in a proper noun should be capitalized. In example 3 , the spelled-out number five in the proper noun the $11^{\text {th }}$ fiveyear National Developing Program should be capitalized, because it is part of the proper noun.

As to whether the abbreviations of the units of measurement are capitalized or not, it largely depends on the conventions. The word $R M B$ in example 4 is the abbreviated form of Renminbi, the unit of Chinese currency. According to the conventions of writing mechanics, all the three letters should be capitalized. While in example 5, the length unit of measurement $K M$ should not be capitalized. The noncapitalized form $\mathrm{km}$ is commonly preferred.

\section{3) Word Division Mistakes}

Example 6: Lang fang City of Universities
In English, two words are separated from each other by a space, while in Chinese it is quite difficult to separate different words from each other. Only Chinese characters can be separated, for each Chinese character covers a square space, making it easy for readers to separate different characters. When the pronunciation of a Chinese character is signified by Pinyin pronunciation symbols, each Pinyin pronunciation symbol corresponds to one Chinese character. Langfang is a city name. The two Pinyin pronunciation symbols together represent one word. Accordingly, lang and fang are supposed to be written as a single word without any space between them, and the first letter should be capitalized, that is Langfang. If they were separated by a space, target readers may get the impression that they are two words respectively and get confused what it refers to.

\section{B. Punctuation Marks Mistakes}

Example 7: Our University has 15 institutional departments, such as the Schools of Civil Engineering, School of Traffic and Transportation Engineering... Department of Mathematics \& Physics and etc.

The abbreviation etc. is frequently used in English writing. The complete form is et cetera, which is originally a Latin word. The et in et cetera means "and"; therefore, and etc. means "and and others." It is illogical. The word and should be cut off, and etc. should stands by itself.

\section{Mistaken Translations of Proper Nouns}

There are many proper nouns in the brief introductions, which signify concepts of Chinese characteristics. The translations of some proper nouns have been officially approved and frequently used in various media, while others have not. It is recommended that translators select the officially approved translations. But mistakes of proper nouns did exist in the English translation of the brief introductions to the universities. Here is a list of those words not properly translated. "Table I"

Some translations were grammatically wrong, such as master degree, doctor degree. The possessive case indicator "s" should follow the word master or doctor. Yet the mistaken translation master degree or doctor degree appeared in more than one brief introductions to the universities of Hebei province.

Some mistaken translations may result from carelessness, for example industry-university, in which only the first two Chinese characters were translated.

Misunderstandings may arise from certain mistaken translations. The Chinese word yán jī̄ shēng include two types of students: those studying for a master's degree, and those studying for a doctor's degree. If it were translated into masters, those doctoral candidates would be excluded. The standard translation should be postgraduate or graduate student. 
TABLE I. Mistaken TRansLation OF PROPER Nouns

\begin{tabular}{|c|c|c|c|}
\hline No. & Chinese & $\begin{array}{c}\text { Mistake } \\
\text { Translation }\end{array}$ & Correct Translation \\
\hline 1 & $\begin{array}{l}\text { shùo shì xué } \\
\text { weì }\end{array}$ & master degree & master's degree \\
\hline 2 & $\begin{array}{l}\text { xué shì xué } \\
\text { weì }\end{array}$ & bachelor degree & bachelor's degree \\
\hline 3 & chăn xué yán & industry-university & $\begin{array}{l}\text { industry-university- } \\
\text { research }\end{array}$ \\
\hline 4 & $\begin{array}{l}\text { kē jì chéng } \\
\text { guǒ }\end{array}$ & $\begin{array}{l}\text { scientific and } \\
\text { technological results }\end{array}$ & $\begin{array}{l}\text { scientific and } \\
\text { technological } \\
\text { findings/achievements }\end{array}$ \\
\hline 5 & yán jiū shēng & master & $\begin{array}{l}\text { postgraduate/graduate } \\
\text { student }\end{array}$ \\
\hline 6 & bó dăo & doctoral adviser & $\begin{array}{l}\text { doctoral tutor/ } \\
\text { supervisor of } \\
\text { candidates }\end{array}$ \\
\hline 7 & biān jí bù & editorial office & editorial department \\
\hline 8 & $\begin{array}{l}\text { chéng rén jiào } \\
\text { yù xué shēng }\end{array}$ & part-time student & $\begin{array}{l}\text { Adult/continuing } \\
\text { education student }\end{array}$ \\
\hline 9 & $\begin{array}{l}\text { wén míng dān } \\
\text { wèi }\end{array}$ & civilized unit & $\begin{array}{l}\text { a model unit/institution/ } \\
\text { establishment in civic } \\
\text { virtues }\end{array}$ \\
\hline 10 & zhuān yè & specialisation & speciality \\
\hline 11 & xiào xùn & banner & motto \\
\hline 12 & hé xīn qī kān & kennel journal & core periodical \\
\hline 13 & kāi fā qū & Developing Zone & $\begin{array}{l}\text { Open Economic Zone /a } \\
\text { development zone }\end{array}$ \\
\hline 14 & wài pìn & external & $\begin{array}{l}\text { to engage (sb) from } \\
\text { elsewhere }\end{array}$ \\
\hline 15 & zú qiú chăng & football ground & football field/pitch \\
\hline 16 & $\begin{array}{l}\text { gāo ěr fū qiú } \\
\text { chăng }\end{array}$ & golf practise range & golf course \\
\hline 17 & tài jí quán & Taiji Quan & Taijiquan \\
\hline 18 & $\begin{array}{l}\text { zhuān rèn jiào } \\
\text { shī }\end{array}$ & professional teacher & full-time teacher \\
\hline 19 & fù jiào shòu & assistant professor & $\begin{array}{l}\text { associate/adjunct } \\
\text { professor }\end{array}$ \\
\hline
\end{tabular}

Misusage of certain words may lead to non-standardized translations. The word adviser means "person who gives advice, especially somebody who is regularly consulted", widely used in different fields. Tutor or supervisor means "university teacher who supervises the studies of a student", which is frequently used to refer to a certain type of teachers in the university. Accordingly, the Chinese word bó dăo was preferred to be translated into doctoral tutor/ supervisor of $P h D$ candidates. Besides, research showed that in western countries, tutor or supervisor is more preferable.

Some mistaken translations were meaningless. External is an adjective, meaning "coming from outside". Take the following sentence as an example: Furthermore, NCIST also has two academicians (external) of the Chinese Academy of Engineering. It was inferred from the Chinese version that, in this situation, external meant "the academicians were invited from the Chinese Academy of Engineering, not being the full-time teachers in NCIST". Here, external did not sound like a native expression. Target readers may not understand what it means if they do not understand Chinese language. The phrase to engage somebody from elsewhere was more preferable and comprehensible.

\section{Confusing Translations}

Example 8: In 2009 the University was approved as one of the Doctorate Program Construction Unit and will begin to offer doctoral programs in three years.

\section{Example 9: 2.6 million kinds of E-books}

Example 10: Its five campuses, located respectively in cities of Baoding, Qinhuangdao, Huanghua and Dingzhou.

Confusing translation may result from lexical mistakes, such as example 8. As it was said in its Chinese version, the doctoral candidates of this university were expected to study there for at least three years. But according to the English version, it meant that this university would provide doctoral programs three years later. The prepositional phrase in three years indicated a future time, modifying the verb offer. Accordingly, confusion arose. If the preposition in were replaced by of, confusion may disappear immediately.

The measurement unit of books should be copy or volume, while the word kind is frequently used to modify journals or periodicals. Journals and periodicals are continuous publications. One kind of journal means "one series of publication". One kind of journal includes many issues of the same journal. On the contrary, books are not continuous publications. The word kind is not appropriate to modify books. It is known that there are different brands of E-book readers. In example 9, target readers may think that the university may collect different brands of E-book readers. But in fact, there are not so many brands of E-books in the world. It actually means "copies of books" instead of "kinds of brands". Here kind was supposed to be replaced by copy or volume.

Confusion in example 10 may result from lack of explanatory notes. There were five campuses. But only four places were listed. It will not lead to confusions to local people, because they have the knowledge that two campuses are located in Baoding city. However, foreigners without the corresponding background information would draw the conclusion that the translator forgets to add to the fifth location of the campus. Explanatory notes were preferred to be added within the following parentheses, that is Baoding (western campus and eastern campuse).

\section{E. Negligence of Cultural Difference}

Example 11: covering $1600 \mathrm{mu}$

Example 12: In 2013, its council was changed, and the newly elected council is constituted by nine organizations including seven power central enterprises, China Electricity Council, and NCEPU.

Example 13: Whampoa Military Academy of the Seismological Community

Example 14: It is located in the capital city of Hebei province, $280 \mathrm{~km}$ south to Beijing.

The measurement unit $m u$ in example 11 is frequently used by Chinese people. It is not used by westerners. Therefore, target readers may have no idea how big the campus is. It was preferred that the corresponding 
measurement unit popular among the world were listed in the explanatory notes or it were directly converted into the measurement unit target readers are familiar with.

The term central enterprises in example 12 referred to state-owned enterprises. It was literally translated from the Chinese word yāng qǔ. Target readers may not have the knowledge of Chinese economic system. They may get confused. In this sense, state owned enterprises was preferred, because it indicated the characteristics of those enterprises, making it easier to be understood by target readers.

Whampoa Military Academy refers to a prestigious military academy in the period of Republic of China, which educated and cultivated many historically famous highranking military officers. Although this academy does not exist now, the phrase Whampoa Military Academy carries the figurative meaning "the best university within a certain field" in Chinese. Without the historical background information, target readers have no idea what the status Whampoa Military Academy occupies. Therefore, they may not understand the meaning of the phrase in example 13, which exactly meant the best university within the field of seismological community.

In order to achieve successful cross-cultural communication, translators may add explanatory expressions to the literal translations of certain Chinese terms, just like example 14. Target readers may know little about the capital city of Hebei Province, but they certainly know the capital city of China. Because they may have a lot of chances to know something about Beijing, the capital city of China, from TV programs or other media. In order to help target readers understand the geographical position of Shijiazhuang, the capital city of Hebei Province, the translator added an explanatory expression, which informed target readers about the closeness of Shijiazhuang to Beijing.

\section{CONCLUSION}

Although the English translations of universities' web pages were supposed to be of high quality, survey showed quite contrary results. Various mistakes existed on the English web sites.

Some translation mistakes would not bring misunderstandings to target readers. They just did not follow the international writing mechanics. But some translation mistakes did influence the information transmission or understanding. On one hand, target readers get information about China mainly from various media, which are required to use officially approved translations. They are familiar with the officially approved translations. If translators employed translations different from the officially approved translations, target readers may get confused whether the meaning of this translated term is the same with that of the officially approved one. On the other hand, the inappropriate selection of words in the translations may lead to misunderstandings, too. Most of the translators in China are not native English speakers. In order to guarantee the quality of their translation, they are supposed to read more authentic language materials and use native expressions.
It should be especially pointed out that some brief introductions to the universities are not readable. It seems that they were just translated by computers without further editing by experienced or qualified translators. Although brief introductions to the universities were just a small part of global communication activities, poor translation may spoil the image of a university, even that of Hebei Province.

Nowadays, China has not been properly or fully understood by the outside world due to totally different cultures. Global communication is a transnational activity. Authorities are expected to pay great importance to it, especially under the background of opening wider to the outside world.

\section{REFERENCES}

[1] Heng Xiaojun, Translation for International Communication Theory and Practice, Beijing: Word Affairs Press, 2011.

[2] Liu Yafeng, Translators' Adaptation and Selection: Research on the Process of Global Communication Translation, Beijing: People's Publishing House, 2010.

[3] Lu Gusun, The English-Chinese Dictionary, Shanghai: Shanghai Translation Publishing House, 2016.

[4] Lu Xiaojun, National Image and Chinese-English Translation Strategies for China's Global Communication, Beijng: Foreign Language Teaching and Research Press, 2015.

[5] Pan Shaozhong, New Age Chinese-English Dictionary, Beijing: The Commercial Press, 2014.

[6] Shi Jian and Shuai Peitian, English Writing Mechanics: Writer's Handbook, Beijing: Foreign Language Teaching and Research Press, 2011.

[7] Zhang Jian, Introduction to Translation in China's Global COmmunication. Beijing: National Defense Industry Press, 2013. 